\title{
Nucleotide Excision Repair
}

National Cancer Institute

\section{Source}

National Cancer Institute. Nucleotide Excision Repair. NCI Thesaurus. Code C20213.

Nucleotide Excision Repair (NER) mends DNA regions that contain chemical adducts, such as UV-induced thymine dimers or carcinogenic adducts, which distort the DNA helix and interfere with replication and transcription. NER is targeted to actively transcribed regions of the genome. During NER in eukaryotes, shape irregularities are detected by protein complexes that slide along the DNA molecule and induce cuts on each side of a lesion several nucleotides away. Removal of the damaged 25-30 nucleotide fragment is followed by repair synthesis and ligation. 